\title{
GENERAL POWER INEQUALITIES BETWEEN THE SIDES AND THE CIRCUMSCRIBED AND INSCRIBED RADII RELATED TO THE FUNDAMENTAL TRIANGLE INEQUALITY
}

\author{
RAZVAN ALIN SATNOIANU
}

Abstract. In this paper we establish the following general triangle inequality between the lengths of its sides $\alpha, \beta, \gamma$, and the circumscribed and inscribed radii $R$ and $r$, respectively:

$$
\alpha^{n}+\beta^{n}+\gamma^{n} \leqslant 2^{n+1} R^{n}+2^{n}\left(3^{1+\frac{n}{2}}-2^{n+1}\right) r^{n} \text { for any } n \geqslant 0 .
$$

This result extends to the general case the results previously known for $n=1,2$ established by W. Blundon $[2,3]$. Our inequality also extends the fundamental triangle inequality.

\section{Mathematics subject classification (2000): 51M16.}

Key words and phrases: geometric triangle inequalities, fundamental triangle inequality, principle of the isosceles triangle.

\section{REFERENCES}

[1] D. S. Mitrinović, J. E. PeČARIĆ AND V. Volenec, Recent Advances in Geometric Inequalities, Kluwer Academic, Dodrecht-Boston-London (1989), 710 pp.

[2] W. J. BLundon, Canad. Math. Bull. 8 (1965), 615-626.

[3] W. J. Blundon, Proposed problem E 1935, American Mathematical Monthly 73 (1966), 1122.

[4] R. A. SATNOIANU, A universal method for establishing geometric inequalities in a triangle, American Mathematical Monthly 108 (2001), 360-364.

[5] R. A. SATNOIANU, The universal principle of the isosceles triangle, submitted (2001). 